\title{
АНГЛОМОВНЕ НАВЧАННЯ ЯК СТИМУЛЯТОР ЯКОСТІ ОСВІТИ ТА МІЖНАРОДНИХ КОНТАКТІВ
}

\author{
В. М. Запорожан, В. Й. Кресюн, М. Л. Арясв, О. В. Чернецька \\ Одеський національний медичний університет
}

\section{STUDY IN ENGLISH AS A STIMULATOR OF EDUCATION QUALITY AND INTERNATIONAL CONTACTS}

\author{
V. M. Zaporozhan, V. Y. Kresyun, M. L. Aryayev, O. V. Chernetska \\ Odessa National Medical University
}

\begin{abstract}
У статті викладено 15-річний досвід викладання студентам-іноземцям англійською мовою і відображено активну міжнародну діяльність науково-педагогічного складу університету з інтеграції медичної освіти України у Світовий освітній простір.
\end{abstract}

The paper presents a 15-year experience of teaching of foreign students in the English language and reflects active international activity of the scientific and pedagogical staff of the University as to the integration of medical education of Ukraine into the world education.

Вступ. Науково-педагогічним складом ОНМедУ проведено значну роботу з впровадження кредитномодульної системи організації навчального процесу, здійснено вагомі кроки щодо інтеграції медичної освіти України у Світовий освітній простір. Особливо це було важливо у світлі перебудови навчального процесу та створення методичного супроводу викладання англійською мовою, бо така організація навчання наближує рівень підготовки фахівців до Європейських стандартів.

Основна частина. Колектив Одеського національного медичного університету першим в Україні (1996) почав здійснювати підготовку іноземних громадян англійською мовою викладання. Навчання студентів англійською мовою стимулює викладачів удосконалювати не лише володіння іноземною мовою, але й свою професійну майстерність. Цим викладачам доступні останні новинки закордонної літератури, вони легко контактують та дискутують зі своїми іноземними колегами, і такі можливості спілкування плідно впливають на якість навчального процесу. Викладання студентам-іноземцям усіх дисциплін англійською мовою дає можливість залучити більше студентів до навчання саме в нашому університеті, підвищує значимість англійської мови у міжнародному спілкуванні, покращує інтеграційні зв' язки, сприяє виходу системи вищої медичної освіти в Україні на якісно новий рівень, що дозволяє розглядати іiі в контексті загальноєвропейських та загальносвітових стандартів. Таким чином, викладання англійською мовою набуває концептуального значення і цьому процесу сприятиме поширення міжнародних контактів. Можливість навчання англійською мовою підвищує престиж університету не лише в Україні, але й за кордоном.

Викладацький склад ОНМедУ спрямовує свої зусилля на реалізацію концепції розвитку вищої медичної освіти в Україні відповідно до загальноєвропейських стандартів та рекомендацій, грунтуючись на кращих традиціях української вищої школи у поєднанні 3 використанням новітніх технологій і досвіду країн Європи. Головним принципом підготовки лікарів на сьогоднішньому етапіє безперервність і ступеневість медичної освіти залежно від кваліфікації, що набувається. У межах введення системи безперервного професійного розвитку лікарів підготовка іноземців англійською мовою в університеті здійснюється як на додипломному, так і на післядипломному етапі.

Насамперед в Одеському національному медичному університеті має місце тенденція до збільшення прийому студентів, які прагнуть навчатися англійською мовою. Так, наприклад, у 2006 році було прийнято на навчання за спеціальністю "Лікувальна справа" 56 осіб, а в 2010 році зараховано 216 студентів та 68 громадян - на спеціальність "Стомато-

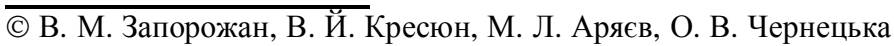


логія”. Усього зараз на міжнародному факультеті університету навчаються 1113 студентів-іноземців, 3 яких 657 - англомовних.

Сприяє зростанню кількості студентів, які навчаються, міжнародний престиж університету, зумовлений співробітництвом 3 Європейською асоціацією університетів (CRE) та Міжнародною асоціацією університетів (IAU), Асоціацією медичних факультетів Європи (Medine) та Великою хартією університетів (Magna Charta Universitatum), Асоціацією приморських університетів (ASU).

3 метою оптимізації навчальної та наукової роботи триває виконання укладених міжнародних угод із 40 зарубіжними навчальними закладами, науковими та науково-дослідними установами, науковими організаціями та фондами. Угодами передбачено участь співробітників ОНМедУ в спільних міжнародних проектах, поліпшення навчально-методичної роботи, обмін викладачами та студентами. 3 професорськовикладацького складу університету понад 30 \% вільно володіють англійською мовою і працюють зі студентами-іноземцями на додипломному етапі навчання. Крім цього, співробітники 8 кафедр університету викладають англійською мовою на післядипломному етапі.

Дві кафедри університету визначені МO3 України як опорні з питань викладання англійською мовою: педіатрії № 13 неонатологією і фізіології. Колективи цих кафедр проводять значну організаційну роботу та здійснюють обмін досвідом, щорічно збираючи на наради завідувачів та викладачів профільних кафедр за різними темами. Так, наприклад, "Удосконалення викладання англійською мовою як складова частина європейської інтеграції вищої медичної освіти в світлі Болонського процесу” тощо.

Ключова позиція - широкий доступ до багатоманітності освітніх і культурних надбань різних країн. Насамперед проблема стосується професійних дисциплін, де лекції набувають характеру оглядових, установчих, а провідне значення мають практичні знання, спрямовані на швидку інтеграцію знань з вміннями і доведення окремих практичних навичок до автоматизму. Оптимізації цієї роботи сприяють міцні зв'язки університету з провідними науковими, освітніми та лікувальними центрами України та зарубіжних країн. Участь вчених університету в спільних програмах і проектах з Польщею, Австрією, Великою Британією, Грецією, Нідерландами, Італією, Росією та ін. надала можливість удосконалювати і використовувати в навчальному та лікувально-діагностичному процесах новітні освітні й медичні технологіі, отримувати гранти, прямі поставки високотехнологічного медичного обладнання, щорічно проводити стажування науковців та викладачів у найкращих навчальних і наукових центрах світу, спільно випускати наукову та навчальну літературу. Так, підручники i посібники англійською мовою підготували співробітники $40 \%$ кафедр.

Триває практика обрання почесними докторами ОНМедУ всесвітньо відомих фахівців у галузі освіти та медицини і їх виступів з лекціями англійською мовою перед студентами та викладачами університету. За активної участі співробітників університету щороку проводиться Міжнародна дистанційна конференція "Нові освітні технології у вузі: теорія і практика". У процесі міжнародної співпраці, особливо 3 Міжнародним Казахсько-Турецьким університетом ім. Ясауї, з'явилась можливість для післядипломної підготовки фахівців і, в перспективі, для підвищення кваліфікації викладачів. Удосконаленню професійної майстерності сприяють закордонні відрядження викладачів і студентів на з'їди, симпозіуми, конгреси, виставки, тренінги, форуми, науково-методичні та науково-практичні конференції тощо, на яких спілкування здійснюється англійською мовою. Усього за 2010 рік в закордонних відрядженнях було 143 фахівці і студенти, з них 62 працівники виступили з доповідями, пройшли наукове стажування та підвищили кваліфікацію.

Зі збільшенням кількості англомовних студентів великого значення набувають збільшення числа і підвищення рівня мовноїпідготовки англомовних викладачів. На кафедрах університету є достатня кількість викладачів для забезпечення занять англійською мовою, але колективи кафедр постійно готують резерв 3 молодих викладачів, аспірантів, магістрів.

Впровадження кредитно-модульної системи організації навчання вимагає від викладачів створення нового навчально-методичного супроводу. Колективи всіх кафедр університету підготували та розмістили на сайтах своїх кафедр на мовах викладання, в тому числі англійській, всі необхідні матеріали для аудиторної та позааудиторної роботи студентів (тексти лекцій, робочі програми, методичні рекомендації для практичних занять, для самостійної роботи студентів, у тому числі підручники, посібники на електронних носіях, банк тестових завдань, питання до модульних контролів тощо). Сьогодні накопичується позитивний досвід щодо гармонізації української освіти 3 освітніми системами світу, наприклад запровадження бліц-освітянських програм, лекцій за принципом “мозкового штурму”, майстер-класів, підготовка 